\title{
Legal Protection Setting of Post-Divorce Women's Rights: Case Study of Siri Marriage in Lombok
}

\author{
Idrus Abdullah 1 \\ Djumardin1 \\ ${ }^{1}$ Lecturer of Faculty of Law, Mataram University, Indonesia
}

\section{Doi:10.5901/mjss.2017.v8n3p297}

\begin{abstract}
Siri marriage, known in various terms such as under hand marriage and undocumented marriage, is a marriage based on religious rules or customs and is not recorded in the Office of Religious Affairs for Muslims or the Office of Civil Registry for non-Muslims. Factors influencing the occurrence of siri marriage are; economy, social, culture, education, and religious beliefs in the legality of siri marriage. The legal consequences of not doing registration of marriages would harm spouses or those who are married even though the marriage is performed in accordance with religion and beliefs because it is considered invalid if it has not been recorded by the Office of Religious Affairs or the Office of Civil Registry. Furthermore, children who are born in an undocumented marriage are considered illegitimate and also only have a civil relationship with mother or mother's family (Article 42 and 43 of the Act on Marriage).
\end{abstract}

Keywords: siri marriage, legal protection

\section{Introduction}

Marriage in Islam has a high religious value, because it is not only a legal action related to legitimating, but also a legitimate affinity relationship between a man and a woman to live together, causing marital relationship (Rahman, 2013). Thus, marriage is a medium that will unite two people in a household and is the sole ritual unifying two people which is officially recognized under the state law and religious law.

To carry out marriage in Indonesia always varies, starting from marriage through the Office of Religious Affairs and the Office of Civil Registry, elopement, and siri marriage, which is popular among the people. Siri marriage is known as under hand marriage, and undocumented marriage.

Siri marriage is one form of marriage practiced by the Sasak people of Lombok. Even, the percentage of siri marriage in Lombok places the highest position in Indonesia. Custom or tradition of elopement makes the number of the case is constantly growing. The authorities, in this case the local government and the Ministry of Religious Affairs, do not have a high power to intervene tradition or prevent such cases, except with a policy that touches on local wisdom.

Chairman of the Religious Court of Selong, Izzudin, H.M., justified the high number case of unregistered marriages. By the fact of East Lombok as the densest population in the province, East Lombok becomes the district with the highest siri marriage cases in Indonesia. The government of East Lombok has actually started observing the development of the case so as not widespread and tried to solve it by establishing isbath marriage program for 3,000 couples which began in 2009.

Siri marriage is a marriage based on religious rules or customs and is not recorded in the Office of Religious Affairs for Muslims or the Office of Civil Registry for non-Muslims. The term comes from Arabic word sirra - israr that means secret (Munawir, 1996). Siri marriage terminologically is defined as a marriage conducted in secret or confidential (Yunus, 1979). This marriage is considered valid based on religion but in violation based on government regulations (Syahar, 1981).

\section{Review on Related Literature}

\subsection{Legal Protection}

One function of law is to provide legal protection for the public. Protection is not only adaptive and flexible, but also 
predictive and anticipative. Law is also required for those who are weak and not strong socially, economically and politically to obtain social justice. Legal protection for people is an act of government that is both preventive and repressive. Law as the system has three subsystems which are substances (principles and rules), structure (institutional), and legal culture (the process of realizing rules into reality) (Friedman, 1986).

\subsection{Post-Divorce Women's Rights}

Article 149 of Compilation of Islamic Law mentions when a marriage ends in divorce, the ex-husband must:

a. provide decent mut ah to his ex-wife, either in the form of money or objects, except the former wife has not had sexual intercourse with the ex-husband (qabla al dukhul);

b. make a living, maskan (house) and kiswah (clothes) to ex-wife during the waiting period, unless the wife has been sentenced to ba'in or nusyuz divorce and in a state of being pregnant;

c. pay off the outstanding dowry in full and in half they have not had sexual intercourse (qobla al dukhul); and

d. give hadhanan costs (living cost) for children who have not attained the age of 21 years.

\subsection{Siri Marriage}

Siri marriage is terminologically not found in the marriage law and in the classical figh munakahat (rules and laws of marriage in Islam). To know the meaning of siri marriage (nikah siri), it can be traced etymologically from the word "nikah" and "sirr". Nikah can be identified with marriage or marriage which is synonymous with the notion of marriage prevalent in figh munakahat or marriage laws. While the word siri (Arabic; plural asrar) refers to secret, mystery, quietly, closed, and concubine (Munawir, 1996).

\section{Method}

This study is a normative legal research, conducted by reference to legal norms contained in the legislation and refers to court decisions. In addition, this study is descriptive analytics which reveals the legislation relating with legal theories as research objects (ali, 2009). The approaches implemented in the study are statute approach, conceptual approach, and case approach.

\section{Discussion}

\subsection{The Setting of Duties and Authorities of the Office of Religious Affairs in Indonesia Marriage Registration}

\subsubsection{Duties and Authorities of the Office of Religious Affairs}

Duties and functions of the Office of Religious Affairs (Kantor Urusan Agama known as KUA) as stated in the Decision of the Minister of Religion No. 517 of 2001 on Structuring Organization of the District Office of Religious Affairs that the task of KUA is to carry out some tasks of Regency or City Office of Religious Affairs in the field of Islamic Affairs in the subdistricts.

In performing these duties, KUA carry out functions, such as conducting statistics and documentation, organizing correspondence, filing, typing and organizing households of the District KUA, and carrying out marriage registration, reconciliation, and fostering care of the mosque, zakat, waqf, baitul maal and social worship, population and development of harmonious family in accordance with the policy determined by the Director General of Islamic Guidance based on the legislation in force.

Registration of marriage is based on Act No. 22 of 1946 which was renewed by Act No. 32 of 1954 with the addition of coverage enacted for the entire territory of Indonesia later which was revised by Act No. 1 of 1974 and until now the changes has not been made again.

Rules of the implementation of marriage registration are solely arranged in the KMA and PMA which are often modified and refined. The last published PMA No. 11 of 2007 is dated June 25, 2007. It is described in PMA Article 5 (1) that:

"Notification on the will of marriage is submitted to the PPN (Petugas Pencatat Nikah/ Marriage Recording Official) of the District where the prospective wife lives." 
Along with the above notion, Article 17 paragraph (1) and (2) states that:

1) Marriage settlement is performed before PPN/ penghulu (Muslim leader)/ vice of PPN on the residential areas of the prospective wife.

2) If the marriage ceremony will be conducted outside the provisions referred to in paragraph (1) prospective wife or the guardian must notify PPN territory of residence the candidate's wife to obtain a recommendation letter marriage (Wahyudin, 2009).

The procedure for marriage registration process includes notification of marriage, marital examination, announcement of the will of marriage, marriage ceremony, and signing marriage certificate and the making of marriage certificate.

\subsubsection{Notification and Inspection of the Will of Marriage}

Penghulu, vice of PPN or BP4 in providing counseling and guidance should encourage the community in planning the marriage in order to perform the following preliminary preparations:

1) Prospective bride/groom should study the science of the household, the rights and obligations of spouses and so forth.

2) In order to improve the quality of the children, prospective bride/groom should check their health and the bride should be given an injection of tetanus toxoid immunization.

3) Each prospective bride/groom should assess whether there is marriage obstruction, either in accordance with the law of marriage or the laws in force. This is to prevent the occurrence of rejection or cancellation of the marriage.

4) Each prospective bride/groom should mutually conduct research on whether they are in love/agree and whether their parents agree/give blessing. It is closely related to letters of consent of both bride and groom and the letter of parental consent, for the letters are not merely a formality.

After the preliminary preparation is done carefully, the people who will get married notify PPN/Penghulu/vice of PPN of the place where the marriage is carried out at least ten working days before the ceremony is held.

Notification of marriage can be done by prospective bride/groom or parents or representatives with letters required, such as:

a) letter of approval of the prospective bride/groom,

b) Birth certificate or birth recognition letter or certificate of origin (birth certificate or birth recognition letter only to be shown and matched with other letters. For administrative purposes, the concerned submit a copy of the document),

c) certificate of parents,

d) certificate for marriage (Model N1),

e) marriage permission letter for prospective bride/groom who are the member of TNI (Tentara Nasional Indonesia/ Indonesian National Soldiers)/POLRI (Polisi Republik Indonesia/ Indonesian Police),

f) bill of divorce/ sues for divorce or bill of divorce book excerpt if the prospective bride/groom is a widow I widower,

g) certificate of death of the husband/wife created by the village head of the place where husband/wife passes away in accordance with $\mathrm{N} 6$ model if the prospective bride/groom is a widow/widower due to the death of the husband/wife,

h) licenses and exemptions for the prospective bride/groom who has not attained the age of 21 years as the provisions of Act No. 1 of 1974 Article 6 paragraph (2) and (3) and Article 7 (1) and (2) as follows:

Article 6, paragraph (2) and (3)

(2) To establish a marriage of a person who has not reached the age of 21 (twenty-one) years old must obtain permission from both parents.

(3) In the case of one of the parents passes away or in a state of not being able to express their will, the license specified in paragraph (2) of this article can be obtained from parent who is still alive or from parent who is able to express their will.

Article 7 paragraph (1) and (2)

(1) Marriage is allowed only when the man reaches the age of 19 (nineteen) years and the woman has reached the age of 16 (sixteen) years. 
(2) In the case of irregularities in paragraph (1) of this Article a dispensation may be requested to the Court or other officials requested by both parents of the man or the woman.

1) The District Head dispensation letter for marriage to take place less than 10 working days after the announcement.

2) PPN/vice of PPN who receive the will of marriage notification has to investigate and examine prospective husband, wife, and marriage guardian about the presence or absence of marriage obstruction.

3) PPN announce the will of marriage.

After these steps, PPN makes Excerpt of Marriage Certificate which is then given to the vice of PPN to be submitted to the husband and wife.

\subsubsection{Marriage Settlement And the Recordation}

Marriage settlement takes place under the supervision/before PPN. After the ceremony takes place, the marriage is recorded in duplicate Marriage Certificate (model N).

1) If the marriage took place outside the Marriage Hall, the marriage is noted on page 4 model NB and signed by the husband, wife, guardian, and witnesses as well as PPN who supervise them. Then, it is immediately recorded in the Marriage Certificate (model N), and signed only by PPN or vice of PPN.

2) Marriage Certificate is read, if necessary translated into a language understood by the person concerned and witnesses and then signed by the husband, wife, guardian, witnesses and PPN or vice of PPN.

3) PPN makes Excerpt of Marriage Certificate (model NA) duplicate, with the same code and number. The number is $(\ldots / \ldots / \ldots / \ldots)$ indicating the serial number in the year, the number of units in the month, the Roman numeral month and the number of years.

4) Excerpt of Marriage Certificate is given to husband and wife.

5) Numbers in the middle on model NB (Marriage Examination List) is given the same number as the number of Marriage Certificate.

6) Excerpt of Marriage Certificate and Marriage Certificate must be signed by PPN. In the case of the vice of PPN who do inspection and attend the ceremony outside the Marriage Hall, the vice of PPN only signs the marriage examination list and in column 5 and 6 and sign the Marriage Certificate in column 6.

7) PPN is obliged to send the Marriage Certificate to the court covering the area of PPN when the last folio in the book of Marriage Certificate has been completed.

8) If the bride/groom is a widow/widower for divorce or contested divorce, PPN tells the court issuing the Bill of Divorce that the widower/widow had been married using model ND form duplicated into 2. After the marriage notification is received. Religious Court sends back sheet II to PPN after the stamps and signatures of the recipient. Furthermore, PPN keeps it together with Marriage Examination List (model NB).

In case the divorce occurs before the enactment of Act No. 7 of 1989 on Religious Courts:

1) PPN make marginal notes ("additional notes") in the earlier Divorce Registration Book that the person has been married to mention the dates and numbers of Excerpt of Marriage Certificate, signed and dated by PPN.

2) In the case of divorce are listed elsewhere, PPN notifies PPN that registers the divorce that the widower/widow had been married using model ND duplicated into 2. Notification recipient PPN notes in the record in "additional notes" in the Divorce Registration Book as mentioned in point 1). Then PPN gives back sheet II model ND after being stamped and signed by the recipient. After that, PPN, who sends the notification after receiving the notification back, saves model ND sheet II together with Marriage Examination List (model NB).

\subsubsection{Will of Marriage Announcement}

PPN/Vice of PPN announces the will of marriage (model NC) on a bulletin board after the requirements are met.

The announcements are made by:

1. PPN in the Office of Religious Affairs of District where the wedding will take place and at the Office of Religious Affairs of District of each bride/groom; and

2. Vice of PPN outside Java in places that are easily known to the public.

PPN/Vice of PPN shall not perform the ceremony before exceeding ten working days of the announcement, except as set forth in Article 3 paragraph (3) PP No. 9 of 1975 that when there is a very important reason, for example, one will be assigned to overseas, it is possible that the relevant pleads dispensation to district head, district head on behalf of the 
Regent granting a dispensation. In ten days, prospective bride/groom should receive advice from local BP4.

\subsubsection{Approvals, permissions and dispensations}

In Act No. 1 of 1974, it is stated a number of principles to ensure the noble ideals of marriage, namely the principle of voluntary, participation of families, polygamy which is severely restricted, and the physical and mental maturity of prospective bride/groom.

As the realization of the principle of voluntary, marriage should be based on the agreement of both parties (bride and groom). Therefore, every marriage must be approved by both parties without any coercion from any other parties to avoid the occurrence of forced marriage. For that reason, Approval Letter of Bride/Groom (model N3) is made.

\subsection{Factors Affecting the Occurrence of Siri Marriage (without a register of P3NTR)}

\subsubsection{Economics}

Economic is one of the factors that affect the citizens who choose siri marriage in Narmada District. Many poor people did not register their marriage due to the costs spent for marriage. The lack of economic income and understanding on the importance of registration of marriage makes some people prefer to have siri marriage which is more affordable than marriage registered to the Office of Religious Affairs which is perceived to be very expensive.

\subsubsection{Social}

1) Early marriage

One culture that has been retained is early marriage. When they register to the Office of Religious Affairs, they would be rejected due to insufficient in terms of age. This causes the parents to take a shortcut by carrying out marriage settlement lead by local community leaders.

2) Desire of polygamy

Siri marriage and polygamy are inseparable. Generally the polygamists who are not licensed by the wife will secretly do a siri marriage, so as not to be known by the wife.

3) Pride to be married to a famous figure

A woman as well as her parents would be proud if she is married to a prominent figure, moreover a religious figure, even though she becomes the second, third, and even fourth wife.

\subsubsection{Custom}

Custom also becomes factor influencing the duties and authority of the Vice of PPN since indigenous plays an important role in the process of marriage on Lombok Island. When marriage is carried out, the process of selarian is often done earlier. However, the report has not been made by the authorized marriage registrar officer be it PPN/Penghulul vice of PPN to carry out investigation in advance about the completeness of the terms of marriage the bride and groom.

\subsubsection{Education}

Low education is also the factor that causes many people choose siri marriage or illegal marriage. Due to dropout, many children who should have spent their time at school studying psychologically and physically feel mature that they decide to get married earlier.

\subsubsection{Legitimacy based on religious belief}

A deep belief in religious figures and the legitimate assumption on siri marriage in accordance with religious teaching makes siri marriage often happen. Society prefers their daughter's marriage is led by religious leaders rather than by the government-appointed penghulu.

In addition, factors causing people to do siri marriage include:

1) Public ignorance of the rules of marriage that was codified in Act No. 1 of 1974 on Marriage, particularly related to the negative impact of the loss of legal rights of marriage. 
2) Underestimate at rules in Act No. 1 of 1974, for normatively syara' (Islamic rules) never questioned registration in a marriage.

In principle, as long as siri marriage meets conditions of marriage agreed by Islamic scholars as described in the books of Fiqh, it is certain that the marriage is essentially legal. Related to the purpose of marriage, Imam Ghozali argued that marriage is to create good generation, and develope human tribes, and preserve humanity from evil and destruction. Siri marriage, in fact, does not fulfill these values. Due to its absence from legal recognition from the State, children born as a result of siri marriage are not considered as citizens. Additionally, when domestic disputes occur, both wife and husband do not have the force of law, thus violence and crime often occur.

Siri marriage is also contrary to the orders of the Prophet, who recommends that marriage should be announced to avoid detraction from the public. Also, declaring marriage is a way to differentiate marriage from adultery

From the above description, it can be concluded that siri marriage, either polygamy or not, is illegal due to the lack of understanding of the law and the lack of legal awareness of the majority of community of the importance of marriage registration. It must be highlighted that siri marriage does not have the force of law.

\subsection{Effects of siri marriage for wife and children in case of divorce}

The negative effects of siri marriage are usually felt by women and children, although seen from religious point of view siri marriage is considered valid. However, seen from legal and sociological point of view, economic responsibilities in siri marriage still need to be reviewed.

Negative effects of siri marriage include:

a) Law

1) The absence of legal protection for women;

2) The absence of legal certainty on the status of children;

3) The absence of force of law for wife and the children in the estate.

b) Economy

1) Lack of force for woman to economically demand a living;

2) Arbitrariness of the husband to provide a living.

c) Sociological

1) The creation of new communities that do not receive appropriate and adequate legal guarantees. When violence is done to the wife, she cannot put it on trial due to the lack of legal force.

2) Increasing the number of young people who are lack of attention and affection of their parents

3) Increasing the number of young people who do not have a chance in obtaining employment.

d) Culture

e) Psychology

Peace and tranquility experienced by women of siri marriage are counterfeit. Tragically, they are drowned into the pseudo happiness and cannot escape from the shackle of insecurity.

The effectiveness of the law is often attributed to its influence on society. Therefore, the essence of legal effect on society is the patterns of citizens' behavior which is in accordance with applicable laws. If the purpose of the law is reached, that is when citizens behave corresponds to the expected or required by law, it is called the effective law.

Soerjono Soekanto said that the laws significantly work if there are four alements which harmoniously work. They are: the law or the rules, officers who enforce it, facilities expected to support the implementation of the law, and the citizens included into the scope of the legislation itself (Soekanto, 1995).

Ineffectiveness of marriage recording might also seriously harm spouses or those who are married because even though the marriage is performed according to the religion and beliefs, but, in the constitutional state, it is considered invalid if it has not been recorded by the Office of Religious Affairs or the Office of Civil Registry. Children born in an unregistered marriage are not only considered illegitimate, but also merely have a civil relationship with the mother or the mother's family.

\section{Conclusion and Suggestion}

\subsection{Conclusion}

The discussion on the above chapters can be concluded as follows: 
a. The Office of Religious Affairs of the District as stated in PMA No. 11 of 2007 is the agency in charge of Department of Religious Affairs carrying out some tasks of Department of Religious Affairs of the Regency or City in the field of Islamic religious affairs in the district area. In performing its role, the Office of Religious Affairs organizes statistics and documentation, organize correspondence, filing, and typing, carry out registration of marriage and reconciliation, and manage and build the mosque, zakat, waqf, baitul maal and social worship, population and development of harmonious family in accordance with the policy determined by the Director General of Islamic Guidance based on the legislation in force.

b. Factors influencing the occurrence of siri marriage are; economic, social, culture, education, and religious beliefs in the legality of siri marriage. In addition, there are factors that affect the duties and authority of the Vice of PPN, such as education, persona in society, and economy.

c. The legal consequences of not doing registration of marriages would harm spouses or those who are married even though the marriage was performed according to the religion and beliefs because it is considered invalid if it has not been recorded by the Office of Religious Affairs or the Office of Civil Registry and children who are born in an undocumented marriage are considered illegitimate and also only have a civil relationship with mother or mother's family (Article 42 and 43 of the marriage Act). Further result of marriage that is not registered is either wife or children born of this marriage are not entitled to demand a living or the inheritance from the father.

\subsection{Suggestions}

a. Act No. 1 of 1974 should be revised because they are blurring the norm in Article 2 paragraph (1) which states that "marriage is legal if carried out based on individual religion and belief". The absence of norm is found in this Act in which legal sanction is absent for those who perform marriages without recording, so that there is no fear and deterrent for the perpetrators.

b. Mass wedding program should be conducted by the Office of Religious Affairs of West Lombok for the poor, as it will greatly help the people with weak economy as well as increase the quality of work of Ministry of Religious Affairs in particular. The costs can be budgeted from DIPA of Ministry of Religious Affairs of West Lombok.

\section{References}

Ali, Z. (2009). Metode Penelitian Hukum. Edition I. Molds 1. Jakarta: Sinar Grafika.

Friedman, L.M. (1975). The Legal System: A Social Science Perspective. New York: Russell Sage Foundation. Kusumaatmadja, M. (1986). Pembinaan Hukum dalam Kerangka Pembangunan Nasional. Bandung: Binacipta. Munawir, A.W. (1996). Kamus Al Munawir. Yogyakarta: Pondok Pesantren Al Munawir.

Rahman, M.F. (2013). Pernikahan di Nusa Tenggara Barat: antara Islam dan Tradisi. Mataram. Leppim IAIN Mataram.

Soekanto, S. and Pamudji, S. (1995). Penelitian Hukum Normatif: Suatu Tinjauan Singkat. Jakarta: Rajawali Press.

Syahar, S. (1981). Undang-undang Perkawinan dan Masalah Pelaksanaannya Ditinjau dari Segi Hukum Islam. Bandung: Alumni.

Wahyuddin, A. (2009). Rivalitas Asas Domisili dan Teritorial Dalam Pencatatan Perkawinan. Cirebon: Alumni.

Yunus, M. (1979). Hukum Perkawinan dalam Islam. Jakarta: Hidakarya Agung. 
ISSN 2039-2117 (online)

ISSN 2039-9340 (print)
Mediterranean Journal of Social Sciences MCSER Publishing, Rome-Italy
Vol 8 No 3

May 2017 